\title{
SISTEM PENUNJANG KEPUTUSAN \\ PENILAIAN PERILAKU KERJA PEGAWAI \\ STUDI KASUS KANTOR DINAS PERINDAG POLMAN
}

\author{
Agustinus Sudi' ${ }^{1}$ Hasnawati ${ }^{2}$, Aco Nasir ${ }^{3}$ \\ 1Universitas Al Asyariah Mandar, ${ }^{2}$ Universitas Al Asyariah Mandar, ${ }^{3}$ Universitas Al Asyariah \\ Mandar Email: andretcmamasa@gmail.com, hasnawatisyaifuddin042@gmail.com
}

\section{ABSTRACT}

This study discusses the decision support system for evaluating employee work behavior carried out at the Polman Industry and Trade Office. Where, the current condition at the Polman Industry and Trade Service itself, the performance appraisal of its employees, especially nonpermanent employees, is still done manually. This makes the need for a system that is able to manage employee performance appraisal data. This study aims to produce a system that can assist agency leaders as consideration in making employee research decisions. To minimize the obstacles faced, in this study apply the Analytic Hierarchy Process (AHP) method in a Decision Support System (DSS). The criteria used in this research are service orientation, integrity, commitment, discipline, cooperation and leadership. This system uses the Visual Basic Net 2010 programming language and Microsoft Office 2003 for the database.

Keywords: support system, perindag, SPK, employees.

\begin{abstract}
ABSTRAK
Penelitian ini membahas tentang sistem penunjang keputusan penilaian perilaku kerja pegawai yang dilakukan di Dinas Perindag Polman. Dimana, kondisi saat ini di Dinas Perindag Polman sendiri, penilaian kinerja pegawainya terutama pegawai tidak tetap masih dilakukan secara manual. Hal ini yang menjadikan perlunya sebuah sistem yang mampu mengelolah data penialain kinerja pegawai. Penelitian ini bertujuan menghasilkan sebuah sistem yang dapat membantu pimpinan instansi sebagai bahan pertimbangan dalam pengambilan keputusan penelitian pegawai. Untuk meminimalkan kendala-kendala yang dihadapi, dalam penelitian ini menerapkan metode Analytic Hierarchy Process(AHP) dalam Sistem Pendukung Keputusan (SPK). Kriteria yang digunakan pada penelitian ini adalah orientasi pelayanan, integritas, komitmen, disiplin, kerjasama dan kepemimpinan. Sistem ini menggunakan bahasa pemograman Visual Basic Net 2010 dan Micosoft Office 2003 untuk database.
\end{abstract}

Kata Kunci: sistem pendukung, perindag, SPK, Pegawai. 


\section{PENDAHULUAN}

Suatu instansi tidak terlepas dari peranan sumber daya manusia yang berada di dalamnya. Kualiatas sumber daya manusia merupakan salah satu faktor yang dapat meningkatkan produktifitas kinerja suatu instansi atau organisasi. Oleh karenanya diperlkan sumber daya manusia yang mempunyai kompetensi, karena kompetensi atau keahlian akan dapat mendukung peningkatan prestasi kinerja pegawai (Eko Nurmianto, 2006). Penialain kinerja haru dilakukan untuk mengetahui pretasi ynag dapat dicapai oleh setiap pegawai. Dengan melakukan proses penilaian kerja maka prestasi yang dicapai setiap pegawai dengan nilai baik, cukup atau kurang bisa diketahui. Penilaian prestasi penting bagi setiap pegawai karena berguan bagi perusahaan untuk menetapkan tidakan kebijaksanaan selanjutnya(Rohmat Taufik, 2011).

Dipihak instansi sendiri mempunyai kendala dalam mengukur kinerja pegawai dilingkup instansi pemerintahan. Selama ini proses penilaian kinerja pegawai di Dinas Perindag Polman belum dilaksanakan secara optimal terutama dalam menilai kinerja pegawai honorer, dimana penilaian pegawai honorer hanya ditentukan dari hasil kerjanya, belum ada kriteria penilaian yang jelas.

Sedangkan penilaian kinerja untuk pegawai tetap menggunakan indikator sasaran kerja pegawai dan perilaku kerja yang terdiri dari 6 unsur, yaitu orientasi pelayanan, integritas, komitmen, disiplin, kerjasama dan kepemimpinan ( Peraturan Pemerintah no.46 tahun 2011).

Selama ini poses penilaian inerja pegawai hononer di subbagian umum dan kepegawaian dinas perindag polman masih dilakukan secara manual, sehingga proses perhitungan cenderung subyektif. Oleh karena itu agar proses penilaian kinerja pegawai menjadi lebih obyektif, sebaiknya dilakukan secara koputerisasi dengan mengembangkan suatu aplikasi penilaian perilaku kerja pegawai honorer dengan mengimplementasikan metode yang tepat.

Pada penelitian ini penulis menggunakan salah satu metode penunjang keputusan yaitu metode AHP (Analytical Hierarchy Process) dan diimplementasikan dalam sistem komputerisasi berupa sistem penunjang keputusan penilaian prestasi kerja pegawai yang menyajikan informasi sehingga dapat membantu pengambil kebijakan dalam menentukan prestasi kerja pegawai.

\section{LANDASAN TEORI}

\subsection{SPK (Sistem Penunjang Keputusan)}

Pada awalnya turban dan aronson, mendefenisikan sistem penunjang keputusan ( decision support systems-dss) sebagai sistem yang digunakan untuk mendukung dan membantu para menajer melakukan penilaian serta menggantikan posisi dan peran manejer. 
Konsep Sistem Penunjang Keputusan pertama kali diperkenalkan oleh Michael S. Scott tahun 1970-an dengan istilah management decision systems. Sistem Penunjang Keputusan dirancang untuk mendukung seluruh tahap pengambilan ketupusan mulai dari mengidentifikasi masalah, memilih data yang relevan, dan menetukan pendekatan yang digunakan dalam proses pengambian keputusan, sampai mengevaluasi pemilihan alternatif(Farabi,2011).

Sistem penunjang keputusan atau decision support systems adalah sebuah sistem yag mampu memberikan kemampuan pemecahan masalah maupun kemampuan pengomunikasian untuk masalah dengan kondisi semi terstruktur dan tak terstruktur. Tujuan dari spk yaitu

a. Membantu menyelesaikan masalah semi terstruktur

b. Mendukung manejer dalam mengamil keputusan

c. Meningkatkan efektifitas bukan

efisiensi pengambil keputusan.

Adapun manfaat dari spk

a. Pengambilan keputusan yang rasional, sesuia dengan jenis keputusan yang perlukan

b. Membuat peramalan

c. Menbandingkan alternatif bukan tidakan

d. Membuat analisis dampak dan membuat model

Adapun karakteristik spk

a. Berfungsi untuk membantu proses pengambilan keputusan untuk memecahkan masalah yang sifatnya semi terstruktur dan tak terstruktur.

b. Bekerja dengan kobinasi model-model dan tehnik-tehnik analisis dengan memasukkan data yang ada dan fungsi pencari informasi

c. Dibuat dengan bentuk yang memudahkan pemakai dengan berbagai instruksi yang interaktif sehingga tidak perlu seorang ahli komputer untuk menggunakannya

d. Sedapat mungkin dibuat dengan fleksibel dan kemampuan adaptasi yang tinggi untuk menyesuaikan dengan berbagai perubahan dalam lingkungan dan kebutuhan pemakai

e. Keunikannya terletak pada dimungkinkannya intuisi dan penilaian pribadi pengambil keputusan untuk turut dijadikan dasar pengambil keputusan

\subsection{Penilain Prestasi Kerja}

Ketentuan yan mengatur pembuatan penilain prestasi kerja pegawai dalam peraturan pemerintah no.46 tahun 2011 tentang Penilain Prestasi Kerja, dlam pasal 1 disebutkan 
a. Pegawai negeri sipil yang diselanjutnya disingkat PNS adalah Pegawai Negeri Sipil sebagaimana dimaksud dal peraturan perundang-undangan

b. Penilain prestasi kerja PNS adalah suatu proses penilaian secara sistematis yang dilakukan oleh pejabat penilai terhadap sasaran kerja pegawi dan perilaku kerja PNS

c. Prestasi kerja adalah hasil kerja yang dicapai oleh setiap pada satuan organisasi sesuai denagn sasaran kerja pegawai dan perilau kerja

d. Sasaran kerja pegawai adalah yang selanjutnya disingkat SKP adalah rencana kerja dan target yang akan dicapai oleh seorang PNS

Dalam pasal 2 disebutkan penilaian kerja PNS bertujuan untuk menjamin adanya objektifitas pembinaan PNS berdasarkan pada sistem prestasi kerja dan sistem karier yang dititik beratkan pada sistem prestasi kerja.

Berdasarkan PP no 46 tahun 2011 pada pasal 4, penilaian prestasi kerja PNS terdiri atas unsur : SKP dan perilaku kerja

Pasal 3 penilaian prestasi kerja PNS dilakukan berdasarka prinsip : objektif, terukur, akuntabel, paritisipatif dan transparan. Pasal 5(1) setiap PNS wajib nenyusun SKP sebagaiman dimaksud dalam pasal 4 huruf a berdasarkan renca kerja tahunan instansi

Pasal 7(1) SKP yang telah disetujui dan ditetapkan sebagaiman dimaksud dalam pasal 5 menjadi dasar penilaia bagi pejabat penilai. (2) Penilaian SKP sebagaimana dimaksud pada ayat(1) meliputi aspek : kuantitas, kualitas, waktu dan biaya

Pasal 12 (1) Penilaian perilaku kerja sebagaimana dimaksud dalam pasal 4 huruf b meliputi aspek orientasi pelayanan, integritas, komitmen, disiplin, kerjasama dan kepemimpinan.

\subsection{Metode Analytic Hierarchy Process(AHP)}

AHP merupakan suatu model pendukung keputusan yang dikembangkan oleh Thomas L. Saaty. Model pendukung keputusan ini akan menguraikan maslah ulti faktor atau muti kriteria yang kompleks menjadi satu hirarki, menurut Saaty(1993) hirarki didefenisikan sebagai suatu representasi dari sebuah permasalahan yang kompleks dalam suatu struktur multi level dimana level pertama adalah tujuan, yang diikuti level faktor, kriteria, dan subkriteria dan seterunya kebawah hingga level terakhir dari alternatif. Dengan hirarki suatu masalah yang kompleks dapat diuraikan dalam kelompok-kelompok yang kemudian diatur menjadi suatu bentuk hirarki sehingga permasalahan akan tampak terstrukur dan sistematis

AHP sering digunakan sebagai metode pemecahan masalah dibanding dengan metode yang lain karena alasan-alasan sebagai berikut : 
a. Struktur yang hirarki, sebagai konsekuensi dari kriteria yang dipilih sampai subkriteria yang paling dalam

b. Memperhitungkan validitas sampai batas toleransi inkosistensi berbagai kriteria dan alternatif yang dipilih oleh pengambil keputusan

c. Memperhitungkan daya tahan output analisis sensivitas pengambil keputusan

Peralatan utama dari model ini adalahsebuah hiraki fungsional dengan input utamanya adalah persepsi manusia. Model AHP memakai persepsi manusiayang dianggap ahli sebagai input utamanya. Kata ahli disini bukan berarti orang tersebut haruslah pintar atau bergelar doktor tetapi lebih mengacu pada orag yang mengerti benar permasalahan yang diajukan, merasakan akibat suatu masalah atau punya kepentingan terhadap masalah tersebut. Jadi perbedaan utama model AHP dengan model lainnya terletapada jenis inputnya. Terdapat 4 aksioma dalam model AHP :
a. Reciprocal comparison
b. Homogenity
c. Independence
d. Expectation

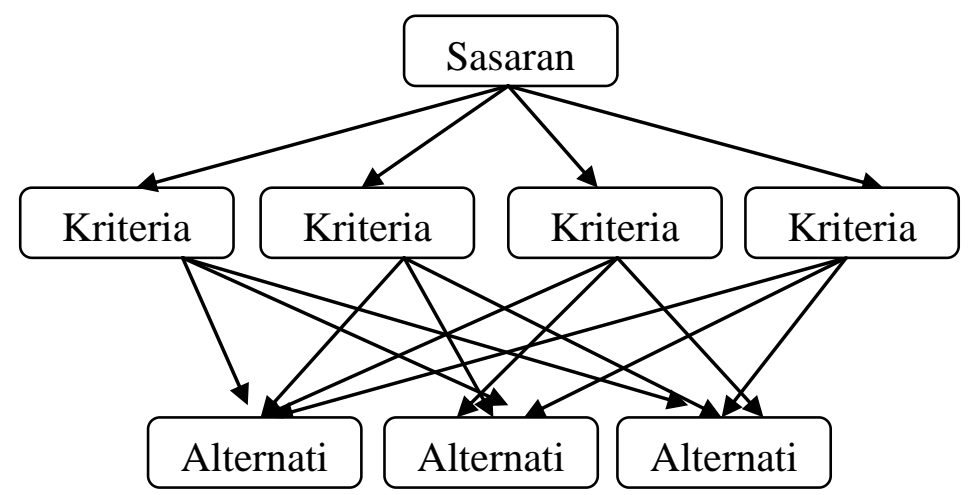

Tahapan metode ahp

a. Menyusun hirarki dari perasalahan yang dihadapi. Persoalan yang akan diselesaikan, diuraikan menjadi unsur-unsurnya, yaitu kriteria dan alternatif

b. Penilaian yaitu kriteria dan alternatif, melalui perbandingan berpasangan

Tabel skala Saaty

\begin{tabular}{|l|l|}
\hline $\begin{array}{l}\text { Intensitas } \\
\text { Kepentingan }\end{array}$ & Keterangan \\
\hline 1 & Kedua elemen sama penting \\
\hline 3 & Elemen yang satu sedikit lebih penting dai \\
\hline
\end{tabular}

108 | MITZAL (Demokrasi, Komunikasi dan Budaya):

Jurnal Ilmu Pemerintahan \& Ilmu Komunikasi 


\begin{tabular}{|l|l|}
\hline & elemen yang lainnya \\
\hline 5 & Elemen satu lebih penting dari elemen lainnya \\
\hline 7 & $\begin{array}{l}\text { Satu elemen jelas lebih mutlak penting dari } \\
\text { yang lainnya }\end{array}$ \\
\hline 9 & Satu elemen mutlak penting dari yang lainnya \\
\hline $2,4,6,8$ & $\begin{array}{l}\text { Nilai-nilai antara dua nilai pertimbangan yng } \\
\text { berdekatan }\end{array}$ \\
\hline
\end{tabular}

Perbandingan dilakukan berdasarkan kebijakan pembuat keputusan dengan menilai tingkat kepentingan satu dengan elemen lainnya. Proses pebandingan berpasangan dimuai dari level paling atas yang ditujukan untuk memilih krteria

Tabel matrix perbandingan

\begin{tabular}{|l|l|l|l|}
\hline $\mathbf{c}$ & $\mathbf{A}_{1}$ & $\mathbf{A}_{2}$ & $\mathbf{A}_{3}$ \\
\hline $\mathbf{A}_{1}$ & $\mathbf{A}_{11}$ & $\mathbf{A}_{12}$ & $\mathbf{A}_{1 \mathrm{n}}$ \\
\hline $\mathbf{A}_{2}$ & $\mathbf{A}_{21}$ & $\mathbf{A}_{22}$ & $\mathbf{A}_{2 \mathrm{n}}$ \\
\hline $\mathbf{A}_{3}$ & $\mathbf{A}_{31}$ & $\mathbf{A}_{32}$ & $\mathbf{A}_{3 \mathrm{n}}$ \\
\hline
\end{tabular}

c. Penentuan prioritas

d. Konsistensi logis. Semua elemen dikelompokkan secara logiis sesuai dengan kriteria yang logis, langkah-langkahnya :

1. Mengalikan matrix dengan prioritas berkesesuaian

2. Menjumlah hasil perkalian perbaris

3. Hasil penjumlahan tipa baris dibagi prioritas bersangkutan dan haslnya dijulahkan

4. Hasil no. 3 , dibagi julah elemen, akan didapat $\lambda_{\max }$

5. Indeks konsistensi $(\mathrm{CI})=\left(\lambda_{\max }-\mathbf{n}\right) /(\mathbf{n}-1)$

6. Rasio konsistensi $=\mathrm{CI} / \mathrm{RI}$, dimaan $\mathrm{RI}$ adalah indeks random konsistensi. Jika rasio konsistensi $\leq 0,1$, hasil perhitungan data dapat dibenarkan Tabel nilai RI

\begin{tabular}{|l|l|l|l|l|l|l|l|l|l|}
\hline $\mathbf{n}$ & 1 & 2 & 3 & 4 & 5 & 6 & 7 & 8 & 9 \\
\hline RI & 0,000 & 0,000 & 0,580 & 0,900 & 1,120 & 1,240 & 1,320 & 1,410 & 1,450 \\
\hline
\end{tabular}

2.4 Microsoft Visual Basic. Net

Visual Basic. Net adalah salah satu bahasa pemrograman komputer tingkat tinggi. bahasa pemrograman adalah perintahperintah yang dimengerti oleh komputer untuk melakukan tugas-tugas tertentu. Bahasa pemrograman VB. Net dikembangkan oleh microsoft yang merupaka salah satu bahasa pemrograman Objeect Oriented 
Program (OOP) atau pemograma yang beorientasi pada objek. Kata visual adalah cara yang digunakan untuk membuat graphical user interface (GUI). Dengan cara ini kita tidak perlu lagi menulisakan intruksi pemrograman dalam kode-kode baris hanya untuk membuat sebuah desaign form.

\subsection{Microsoft Access}

Microsoft Access 2003 atau lebih dikenal access 2003 merupakan salah satu perangkat lunak yang diperuntukkan untuk mengolah database dibawah sistem windows yang merupakan bagian dari Microsoft Office. Database Access 2003 yang disimpan kedalam sebuah file memiliki ektensi .mdb

Ada beberapa istilah yang harus diketahui saat bekerja dalam lingkungan access 2003 yaitu :

a. Table, sekumpulan data yang memiliki topik tertentu, tabel mengatur data yang ada didalam berbentuk kolom

b. Field, tempat atau dimana data atau informasi dalam kelompok yang sama atau sejenis

c. Record, data lengkap dalam jumlah tunggal yag biasanya tersimpan dala bentuk baris secara horizontalpada tabel

\section{METODE PENELITIAN}

Alat yang digunakan dalam penelitian ini adalah hardware : Processor Intel $(R)$ core 2 Duo CPU, Meory 2 GB RAM, VGA Intel(R) HD Graphic family 784 MB, Harddisk 3 GB, dan software: Sistem Operasi windows7 ultimate, database mcrosfot office access 2003, bahasa pemrograman VB Net 2010 Ultimate. Adapun bahan penelitian yang duunakan merupakan objek dari penelitian, yaitu konsep penilaian kinerja PNS Disperindag untuk mencapai suatu prestasi kinrja pegawai yaitu daftar penilaian pelaksanaan pekerjaan (SKP). Untuk analisis data maka metode yang digunakan adalah metode peneitian deskriptif, yang bertujuan untuk menjelaskan suatu keadaan, objek atau segala sesuatu yang terkait dengan variabel yang bisa dijelaskan angka maupun kata-kata.

\section{HASIL DAN PEMBAHASAN}

\subsection{Analisis Masalah Yang Sedang Berjalan}

Berdasarkan hasil penelitian, masalah yang terjadi selama ini dalam proses penilaian prestasi kerja pegawai di dinas perindag polman, belum dilaksanakan secara optimal terutama dalam menilai kerja pegawai tidak tetap/honorer dan masih dilakukan manusal sehingga menyebabakan kendala dalam efektifitas unutk melakukan pengolahan data itu sendiri. Selama ini penilaian pegawai tidak tetap/honorer hanya ditetukan dari 
kehadirannya saja, blum adanya kriteria penentuan yang jelas dalam menentukan hasil kerja yang perlu dipertimbangkan, pada akhirnya proses penilaian prestasi kerja cenderung ebih subjektif sehingga keputusan yang diambil kurang berkualitas. Dalam diagram alir berikut, menggambarkan secara umum proses penilaian pegawai

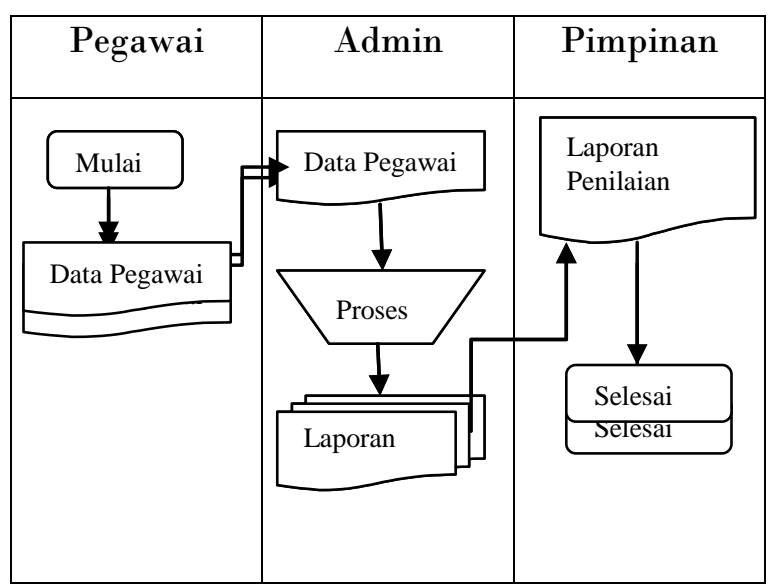

Gambar 1. Bagan alir sistem yang berjalan.

4.2 Analisis Kebutuhan Sistem Yang Diusulkan

Untuk mengatasi masalah yang ada dalam penilaian prestasi pegawai tidak tetap di Dinas Perindag Polman maka penulis mengusulkan penyelesaian masalah pada sistem yang berjalan saat ini yaitu merubah proses yang dilakukan sebelumnya secara manual kini dapat dilakukan scara komputerisasi dan hasilnya dapat disimpan dalam basis data. Prosedur pengelolaan data yang diusulkan adalah sebagai berikut.

Gambar 2. Bagan alir sistem yang diusulkan.

4.3 Perancangan Sistem

Tujuan perancangan sistem ini untuk memberikan gambaran secara umum kepada user mengenai cara kerja sistem yang akan dibuat. Desain sistem menggunakan data flow diagram untuk menggambarakan arus data dalam suatu sistem mulai dari input sampai output. Adapun diagaram konteks yang diusulkan adalah sebagai berikut. 
Agustinus Sudi, Hasnawati, Aco Nasir

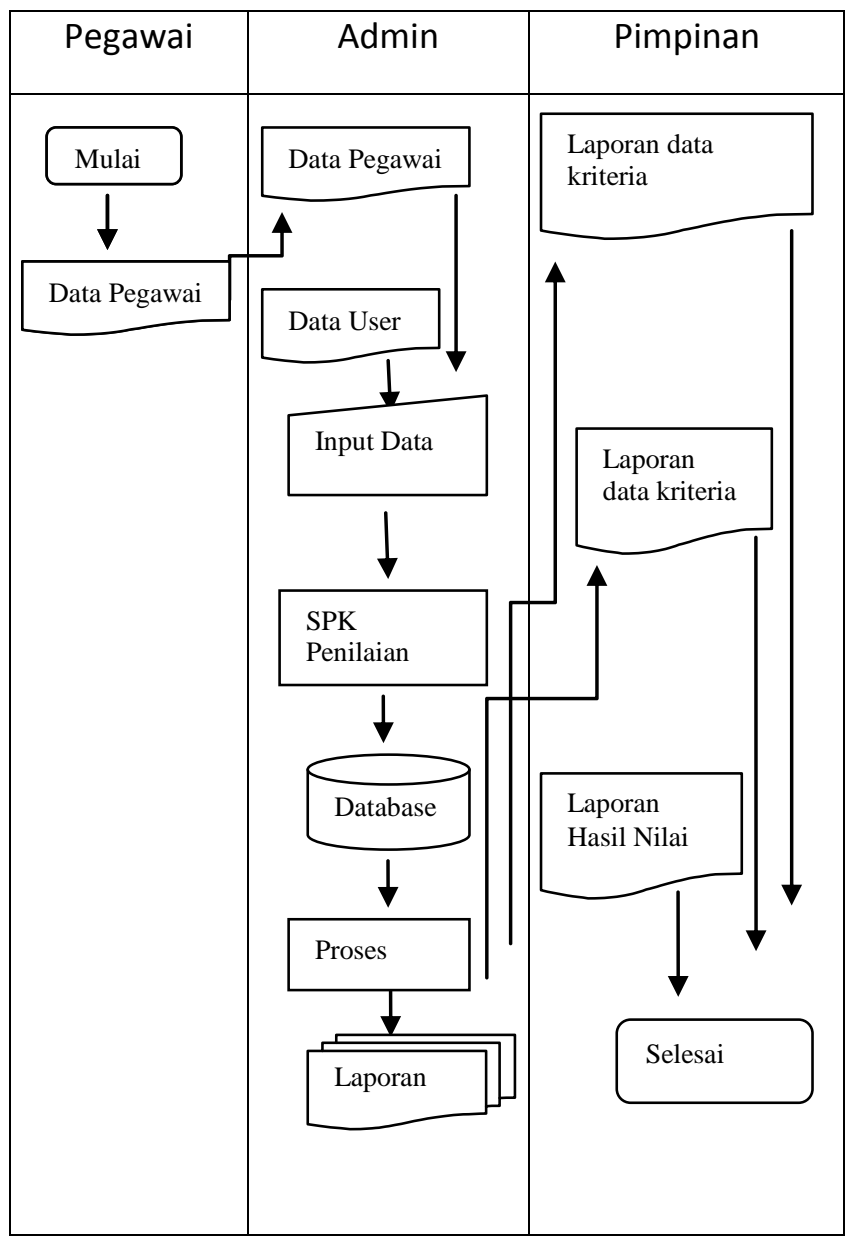

112 | MITZAL (Demokrasi, Komunikasi dan Budaya):

Jurnal Ilmu Pemerintahan \& Ilmu Komunikasi 


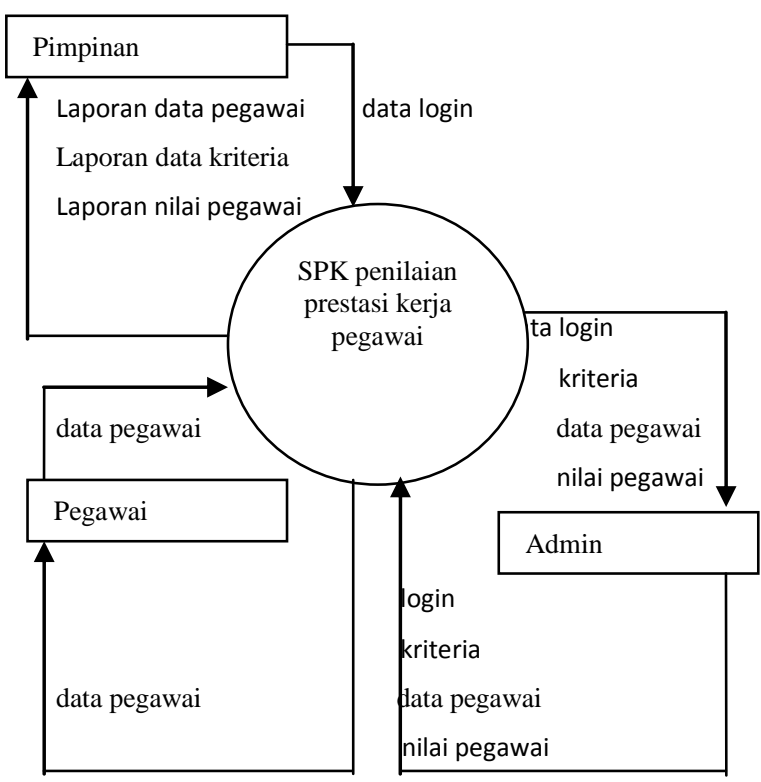

Gambar 3. Diagram Konteks

\subsection{Implementasi Sistem}

Sistem ini berbasis dekstop sebuah aplikasi yang dirancang khusus untuk penilaian prestasi kerja pegawai. Adapun tampilan pada menu aplikasi ini adalah sebagai berikut

a. Tampilan menu login

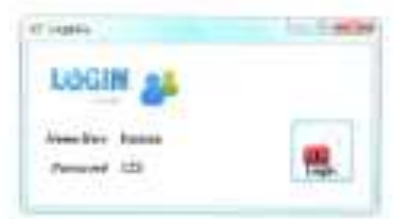

b. Tampilan menu utama

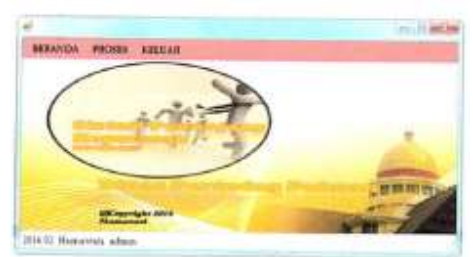

\subsection{Pembahasan}

Kriteria untuk menentukan penilaian perilaku kerja adalah orientasi pelayanan, integritas, komitmen, disiplin, kerjasama dan kepemimpinan 
Agustinus Sudi, Hasnawati, Aco Nasir

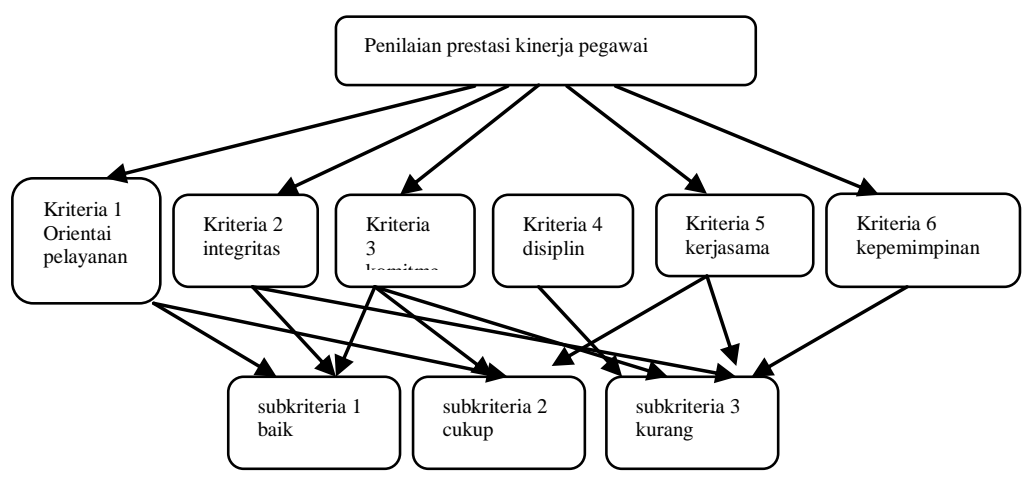

Gambar 4. Urutan stuktur hirarki penilain prestasi kerja

\section{KESIMPULAN}

Berdasarkan uraian pada bab-bab sebelumnya, maka penulis dapat menarik kesimpulan, dari hasil pengujian telihat sistem telah berjalan dengan baik, dan fitur fitur menu pada aplikasi dapat berjalan dengan semestinya. Dimana sistem penunjang keputusan ini memberikan fasilitas bagi admin untuk melihat hasil nilai kriteria pegawai dan melakukan perubahan perhitungan bobot masing-masing kriteria.

\section{DAFTAR PUSTAKA}

Armadyah Amborowati, 2009. Sistem Pendukung Keputusan Pemilihan

Karyawan Berprestasi Berdasarkan Kinerja(Studi Kasu Pada

Universitas Gunadarma Depok)

Dian Novian, 2010. Sistem Pendukung Keputusan Mutasi, Enumerasi, dan Promosi Pegawai Menggunakan Metode AHP

Diditsetyo, 2012. Microsoft access diunduh 18/12/2015, 10:1

Duncan mackenzie \& kent sharkey, atau belajar sendiri dalam 21 hari visual basic.net, bayu probo, yogjakarta : andi,2002

Endang Lestari, Analisa Sistem Pendukung Keputusan Untulk Proses

Kenaikan Jabatan Pada Pt. X, Jurusan Sistem Informasi Fakultas Ilmu Komputer Universitas Sriwijaya Jurnal Sistem Informasi(Jsi) Vol.

1,No3, Desember, 2009

Eko Nurmianto, Dkk, 2006. Perancangan Penilian Kinerja Karyawan

Berdasarkan Kompetensi Spencer Dengan Metode AHP( Studi Kasus Di

Subpengairan, Dinas Pekerjaan Umum, Kota Probolinggo)

FARABI, 2011. Materi SPK.Pdf, Diakses 04/01/2016

Fathansyah,1999, Basis Data, Informatika Bandung

Laporan Akuntabilitas Kinerja Instansi Pemerintah (Lakip) Tahun 2013 